\title{
Refurbishment and Installation of a Monitoring and Early Warning System on the Sierroz Embankments in Aix-les-Bains, France
}

\author{
Jean-Robert Courivaud ${ }^{1, a}$, Rémi Béguin ${ }^{2}$ and Thierry Monier ${ }^{3}$ \\ ${ }^{1}$ EDF - CIH - Savoie Technolac - 73373 Le Bourget du Lac Cedex, France, \\ ${ }^{2}$ geophyConsult - 159, quai des Allobroges -73000 Chambéry, France, \\ ${ }^{3}$ ARTELIA - 6, rue de Lorraine - 38130 Echirolles, France
}

\begin{abstract}
Sierroz embankments are located in an urban area, in the city of Aix-les-Bains (Savoie, France). Their linear is $400 \mathrm{~m}$ on both rims. These embankments protect about 900 people against Sierroz river floods. Hydraulic studies performed in the frame of the Aix-les-Bains Inundation Risk Prevention Plan (PPRI in French) have shown that these embankments have a high risk of failure by overtopping during a 100 year return period flood of the Sierroz River. These studies have defined inundation maps with High Danger areas. From these results, the city of Aix-lesBains asked EDF to perform a safety assessment study, in order to assess the safety margins of these embankments for each of their potential failure modes: overtopping erosion, internal erosion, slope sliding and liquefaction. This study confirmed that the main risk is breaching by overtopping erosion during flood. This diagnosis led the city of Aix-les-Bains to launch two parades: (i) the embankment refurbishment in order to provide them satisfactory safety margins during a 100 year return period flood and (ii) a monitoring and early-warning system able to alert population at risk as early as possible when breaching is imminent. These two parades are presented including environmental constraints and cost estimates.
\end{abstract}

\section{The safety issue of Sierroz embankments in Aix-les-Bains}

The Sierroz River is a tributary of the Bourget Lake, which crosses the city of Aix-les-Bains before its mouth in lake. Sierroz embankments are located between the Red bridge, upstream, and the railway bridge, downstream. Their linear is $400 \mathrm{~m}$ on both rims. These embankments protect about 900 inhabitants against Sierroz River floods. A view of the Sierroz River and its embankments is shown on the Figure 1.

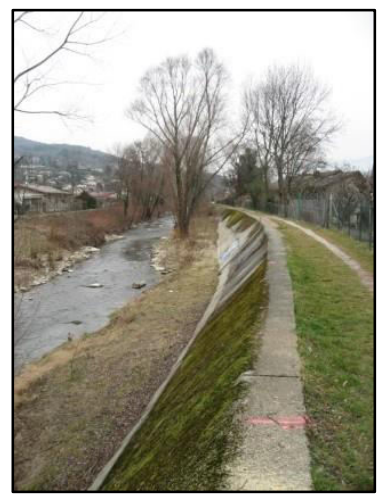

Figure 1. The Sierroz River and its embankments

Hydraulic studies were performed in the frame of the Aix-les-Bains Inundation Risk Prevention Plan (PPRI

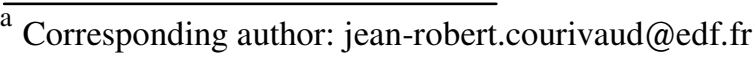

in French). These hydraulic studies predicted inundation characteristics for a 100 year return period flood of the Sierroz River. They highlighted a high risk of failure of the Sierroz embankments in this condition and helped to define inundations maps with High Danger areas, called Red zones in the PPRI, where the risk of casualties is high.

After these studies, the city of Aix-les-Bains decided to improve the security of inhabitants living in these High Danger areas by implementing the following methodology:

1. Performing a safety assessment study, in order to assess the safety margins of these embankments for each potential failure mode: overtopping erosion, internal erosion, slope sliding and liquefaction. This safety assessment study was achieved by EDF and led to define precisely which structural components of the embankments are not satisfactory and what is their linear.

2. Launching two parades from the conclusions of the safety assessment study: the refurbishment of the embankments and the design and implementation of a monitoring and early-warning system. The refurbishment project is currently performed by EDF, ARTELIA, geophyConsult and 
BIOTEC. The monitoring project is currently performed by EDF and geophyConsult.

The embankment characteristics and the main results of the safety assessment study are firstly presented. In a second part, two refurbishment options studied in the design phase are then exposed. Finally, the monitoring and alert systems designed for real-time surveillance during floods are presented.

\section{Safety assessment study}

The safety assessment study followed the EDF methodology, including the following ten steps $[1,2]$. The analysis of the risk of failure by shear under seismic loading was studied but is not presented in this paper, which is focussed only on flood risks.

1. Selection of the loading conditions.

2. Selection of the potential failure modes.

3. Historical data collection and review.

4. Visual inspection.

5. Complementary surveys (topographic, geophysical, geotechnical).

6. Definition of the embankment models.

7. Analysis of the risk of failure by slope sliding under static loading.

8. Analysis of the risk of failure by external erosion (including overtopping erosion and toe undermining erosion).

9. Analysis of the risk of failure by internal erosion.

10. Conclusion on the safety margins of the embankments.

The main results of these steps are presented hereafter.

\subsection{Selection of the loading conditions}

Loading conditions taken into account in the safety assessment study are:

- A stationary Sierroz River level corresponding to the peak flow of a 100 year return period flood (Peak flow equal to $140 \mathrm{~m}^{3} / \mathrm{s}$ ).

- A vertical stress of $10 \mathrm{kPa}$ on the embankment crest corresponding to the circulation of heavy vehicles on the crest.

\subsection{Selection of potential failure modes}

Selected potential failure modes are:

- Slope sliding under static loading.

- Overtopping erosion.

- Upstream toe undermining erosion.

- Internal erosion.

\subsection{Historical data collection and review}

Sierroz embankments were built in the years 18351875 in order to protect the railway Annecy-Chambéry against Sierroz River floods. They replaced older defence structures built around 1750. These embankments were improved several times until the annexation of Savoy to
France. No document related to the construction of these embankments could be found in the regional archives. However, it was found that embankments located downstream on the Sierroz River were built by the French administration in the years 1879-1881 with a similar design. It is reported that these embankments were constituted on gravels. Their upstream face was protected by a masonry wall inclined at $45^{\circ}$ with a rockfill toe. Their downstream slope was $3 \mathrm{H} / 2 \mathrm{~V}$. The masonry wall of the upstream face is still visible on the Sierroz embankments (Figure 2).

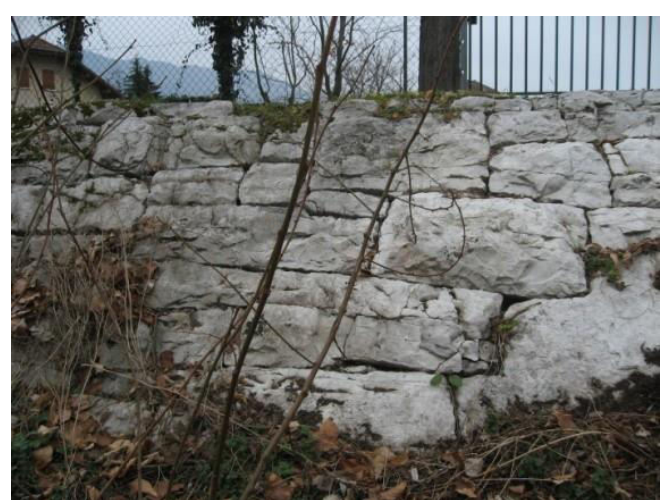

Figure 2. Masonry wall protecting the upstream face of the embankments

The left rim embankment was reinforced along $157 \mathrm{~m}$ after the important damages due to the flood that occurred on 30 September 1960, which peak flow remains unknown. The upstream face of this embankment was reinforced by a $25 \mathrm{~cm}$ thick concrete wall with a 1H/1V slope (Figure 3).

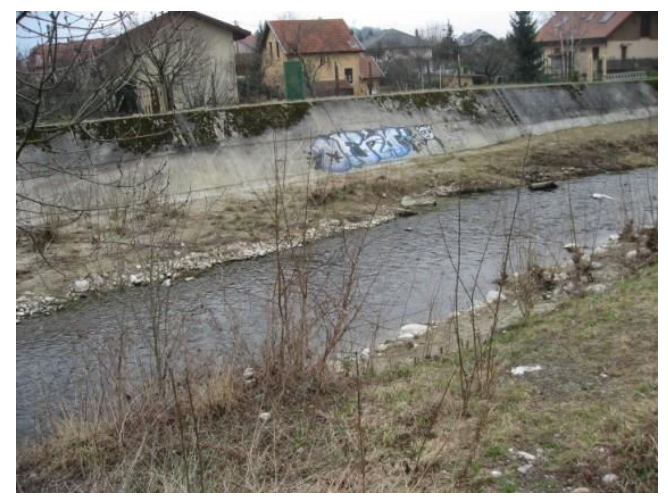

Figure 3. Concrete wall constructed in the years 1960 to reinforce the upstream face of the left rim embankment

Despite no map older than the date of construction of Sierroz embankments could be found, it is highly probable that these embankments intercept former arms of the Sierroz River. These intersection zones can be weak area of the embankment's foundation against the internal erosion and/or liquefaction risks.

\subsection{Visual Inspection}

Along all their linear, the downstream face of the Sierroz embankments belongs to several private properties and has not been maintained as a downstream face of an embankment devoted to flood protection. It has 
been transformed as slopes of private gardens. Some owners transformed the downstream fill of the embankment by constructing a retaining wall without respecting the state of the art rules for that kind of structure (Figure 4). In some cases, the house itself was partly built inside the downstream fill of the embankment.

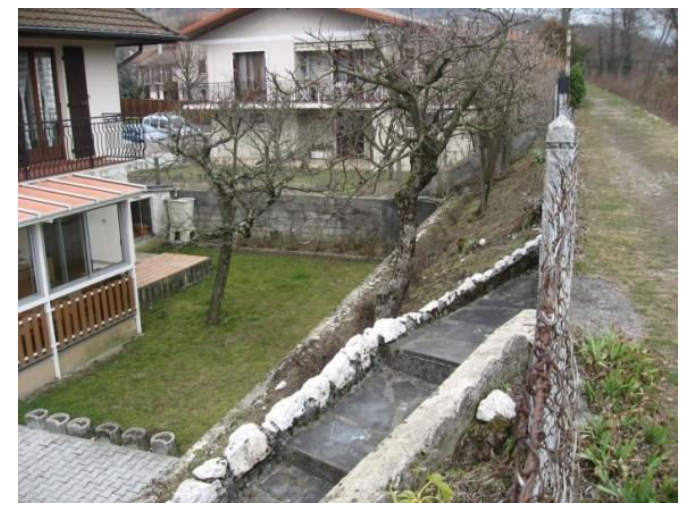

Figure 4. Retaining wall constructed without respecting the state of the art rules for that kind of structures

The lower part of the upstream face of the embankments is covered by sediment deposits carried by the Sierroz River during floods. A lot of vegetation has developed in these sediment deposits, including large trees.

\subsection{Complementary surveys}

Complementary surveys have included topographic surveys, geophysical surveys and geotechnical surveys.

\subsubsection{Topographic survey}

Profiles along the embankment crests, along the downstream toe and four cross sections (two on each rim) were performed. These profiles highlight that the embankment height above the River bottom is about $4 \mathrm{~m}$. The maximum embankment height above the natural ground downstream is $5.10 \mathrm{~m}$ on the left rim and $3.8 \mathrm{~m}$ on the right rim. The cross section profiles confirm the downstream slopes indicated by historical data $(3 \mathrm{H} / 2 \mathrm{~V})$.

\subsubsection{Geophysical survey}

Resistivity and radar measurements were performed along the embankment crests. The objective of these measurements was to provide information on the nature of materials constituting the embankments and their foundation. On the left rim, these surveys show a homogeneous high resistivity (300 to $5000 \Omega \mathrm{m}$ ) 3 to $4 \mathrm{~m}$ deep layer corresponding to the gravely embankment. Below this layer, a low resistivity layer was shown between 4 and $12 \mathrm{~m}$ deep, corresponding to finer/wet materials.

On the right rim, these surveys haven't shown any structure, which means similar materials constituting the embankment and its foundation.

\subsubsection{Geotechnical survey}

In order to meet the different constraints of these embankments (difficult access to the crests, narrow crests), geotechnical surveys consisted in four $12 \mathrm{~m}$ deep core drillings (Figure 5) performed from the crest (named left rim upstream, left rim downstream, right rim upstream and right rim downstream). Laboratory tests were then performed on the core samples (identifications tests, sieve curves, CD triaxial tests on undisturbed fines samples and Jet Erosion Tests on clayey silts and sandy silts).

The water table was identified between 4.5 and $6 \mathrm{~m}$ below the ground level.

These surveys highlighted homogeneous sandy gravels materials on the left rim upstream core samples. For both right rim upstream and downstream core samples, these surveys showed an embankment body made of sandy gravels, an upper layer in the foundation made of clayey silts and a lower layer in the foundation made of sandy gravels. In the right rim downstream core samples, these surveys showed a fine sands layer between the embankment body and the clayey-silty upper layer of the foundation.

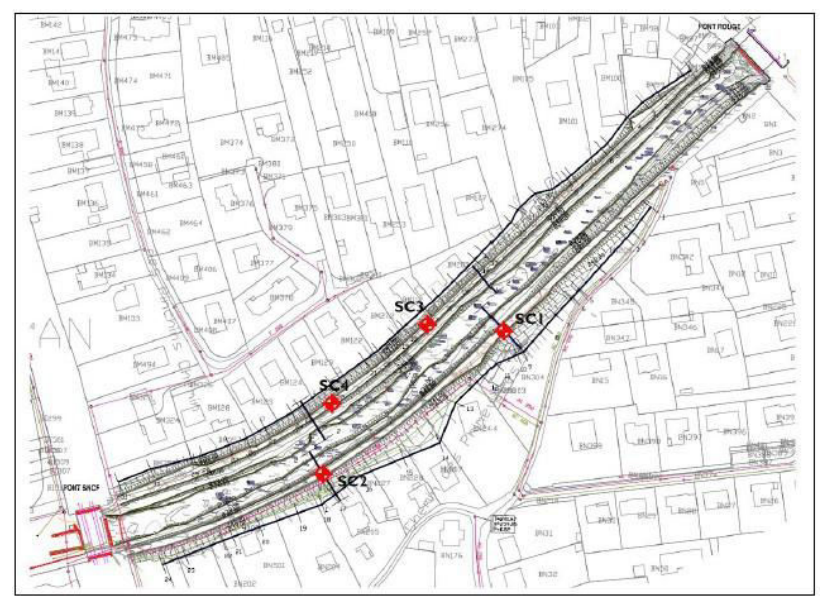

Figure 5. Location of the four core drillings. Red bridge located at the right end and railway bridge located at the left end.

\subsection{Definition of the embankment models}

Embankment models are a simplified but realistic and careful representation of the complex reality of the embankment and its foundation. They are used for the different analysis of the risk of failure. For models are defined:

- The geometrical model.

- The geological model.

- The geotechnical model.

- The hydraulic model.

\subsubsection{Geometrical model}

Sierroz embankments were modelled at four crosssections (two on each rim) corresponding to the highest heights above the ground level downstream, and/or to the highest consequences downstream in case of failure, and/or to the weakest geotechnical characteristics of 
materials constituting the embankment and its foundation. The geometries of these four cross-sections were deduced from the topographic survey.

\subsubsection{Geological model}

At each modelled cross-section, the geological model was defined from the geophysical and geotechnical surveys, including types of materials and material layers' geometries.

\subsubsection{Geotechnical model}

For each type of material constituting the embankments and/or their foundation, careful estimates of the mechanical resistance properties (wet density, effective cohesion and friction angle) have been determined from the laboratory tests.

\subsubsection{Hydraulic model}

The hydraulic boundary conditions are stationary. The hydraulic loading on the upstream face of the embankments is the maximum water level of the 100 year return period flood in the Sierroz River. The hydraulic loading on the downstream boundary of the hydraulic model is the estimated maximum level of the water table. Permeability of materials constituting the embankments and their foundation was carefully estimated from sieve curves and the EDF experience in that kind of modelling.

The geometric, geological and hydraulic models at the cross-section located downstream on the left rim are presented on the Figure 6.

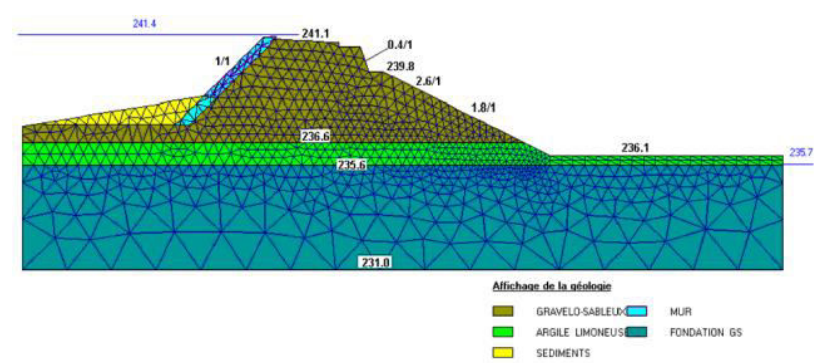

Figure 6. Geometric, geological and hydraulic models at the cross-section located downstream on the left rim.

\subsection{Analysis of the risk of slope sliding under static loading}

Minimum safety factors range for the four crosssections, from 1.11 to 1.18 for a required safety factor of 1.4 (Figure 7). Safety margins of these embankments for the risk of slope sliding under static loading are thus not satisfactory.

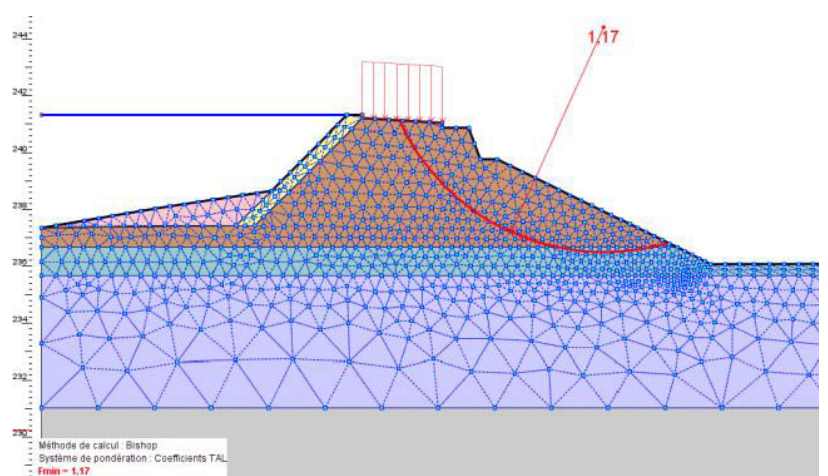

Figure 7. Slope stability analysis at the cross-section located downstream on the left rim.

\subsection{Analysis of the risk of overtopping erosion}

The risk of overtopping erosion was assessed on each embankment by comparing both profiles of the maximum River level (at the peak flow) and the embankment crests altitudes.

On the right rim embankment, an overtopping flow would occur along $100 \mathrm{~m}$ upstream from the railway bridge, with a maximal overtopping height of $42 \mathrm{~cm}$.

On the left rim embankment, an overtopping flow would occur along $140 \mathrm{~m}$ upstream from the railway bridge, with a maximal overtopping height of $42 \mathrm{~cm}$.

For both embankments, the risk of breach during a 100 year return period flood is highly probable.

\subsection{Analysis of the risk of upstream toe undermining erosion}

The risk of upstream toe undermining erosion is restricted in the curvature of the Sierroz riverbed, on the last $200 \mathrm{~m}$ of the left rim embankment upstream to the railway bridge. Sediment deposits on the upstream toe of the embankments tend to limit this risk. However, damages caused by the 1960 flood and the probable undermining toe erosion that occurred must lead to caution. Without any information on the upstream face concrete wall toe, it was not possible to assess the risk of undermining erosion and forthcoming surveys were recommended.

\subsection{Analysis of the risk of internal erosion}

The analysis of the risk of internal erosion has shown that suffusion and backward erosion could initiate during the project flood. During the progression phase of internal erosion, backward erosion could lead to important embankment settlements at the cross-section where a fine sand layer was detected in the upper part of the foundation. If such settlements appeared during a 100 year return period flood, this could lead to a breach by overtopping.

\subsection{Conclusions of the safety assessment study}

This safety assessment study of the embankments of the Sierroz River highlighted that these structures doesn't 
have satisfactory safety margins for the risk of slope sliding, overtopping erosion and internal erosion, during a 100 year return period flood. The main risk is a breach by overtopping erosion which is likely for this flood along the last $100 \mathrm{~m}$ of the right rim embankment upstream the railway bridge and along the last $140 \mathrm{~m}$ of the left rim embankment upstream this same bridge.

In order to recover satisfactory safety margins, two parades were recommended:

- A structural reinforcement of the embankments enabling to avoid overtopping flows during a 100 year return period flood.

- The implementation of a monitoring and earlywarning system in order to perform real-time surveillance during floods and to alert people living in the High Danger Area as soon as possible when a breaching process is likely.

Following these recommendations, the city of Aixles-Bains decided to launch two projects:

- A project dedicated to the structural reinforcement of the embankments. Its objective is to recover satisfactory safety margins to the Sierroz embankments to all potential failure modes.

- A project dedicated to the implementation of monitoring and early warning systems in order to perform real-time surveillance during floods and to be able to alert as soon as possible inhabitants living in the High Risk Area that an imminent breach can occur.

\section{Refurbishment project} triple:

The objectives of the refurbishment project were

- Avoiding overtopping of the embankments during a 100 year return period flood.

- Providing an effective defence barrier against the risk of internal erosion.

- Providing satisfactory safety margins in slope stability.

Two solutions of structural reinforcement were studied in parallel by EDF and ARTELIA. These solutions have been defined in order to take into account the environmental constraints of the embankments: impossibility of reinforcing the downstream slopes of the embankments (located on private properties), impossibility of constructing a diaphragm wall due to a narrow crest. The two solutions which have been studied are:

- Reinforcement of the upstream slopes using rock-fills and a toe berm protected by a filter.

- Reinforcement by sheet piles driven from the embankment crest.

\subsection{Environmental context}

This project includes two main environmental issues:

- Fish transit: during works as well as after completion, fish transit must not be affected.

- Trees management: large trees are located in the river bed. Their roots weaken the embankments and they will be obstacles during works. However, it would be very difficult to get the acceptance to remove them.

The acceptability of solutions to these issues proposed by each option will be one the main criterion to decide which option will be finally chosen.

Chemical analysis of the sediment deposits on the riverbed banks have been performed in order to determine if specific care needs to be anticipated. This analysis has shown no dangerous pollutants in these sediments.

\subsection{Hydraulic modelling}

Several hydraulic modelling of a 100 year return period flood of the Sierroz River between the Red and railway bridges were performed with HEC Ras model (Figure 8) considering several hypothesis of partial obstruction of the flow path below the railway bridge (downstream boundary condition). This modelling allowed to define precisely linear of left rim and right rim embankment which would be overtopped and linear which need to be reinforced.

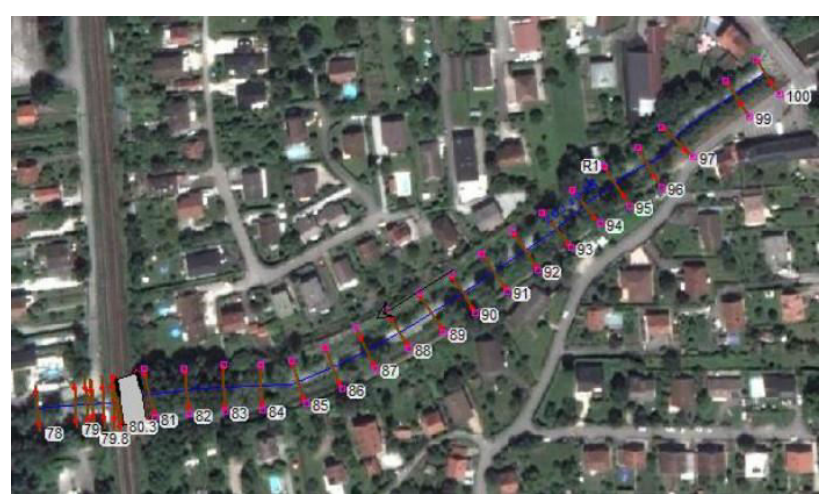

Figure 8. HEC Ras model of the Sierroz River between the Red bridge (right end) and the railway bridge (left end).

\subsection{Reinforcement of the upstream slopes}

$300 \mathrm{~m}$ of embankment need to be reinforced on the right rim and $280 \mathrm{~m}$ of embankment need to be reinforced on the left rim. Four types of reinforcement have been defined for both rims:

- Reinforcement type 1: embankment section with a masonry wall on the upstream face, enhance of the embankment crest elevation, no sealing of the masonry wall, no upstream toe berm. 
- Reinforcement type 2: embankment section with a masonry wall on the upstream face, no enhance of the embankment crest elevation, sealing of the masonry wall, construction of an upstream toe berm with rock fills.

- Reinforcement type 3: embankment section with a masonry wall on the upstream face, enhance of the embankment crest elevation, sealing of the masonry wall, construction of an upstream toe berm with rock fills.

- Reinforcement type 4: embankment section with a concrete wall on the upstream face, enhance of the embankment crest elevation and refurbishment of the concrete wall where necessary.

This reinforcement's design improves the following defence barriers of the embankments:

- There is no more risk of overtopping during a 100 year return period flood thanks to the crest elevation enhance by the construction of a concrete wall on the edge of the embankment crest.

- The risk of the upstream toe undermining erosion is reduced by the upstream toe berm made of rock-fills.

- The risk of internal erosion is reduced by the geotextile filter placed below the rock-fills of the toe berm.

- The sealing of the upstream masonry wall improves the slope sliding risk by reducing pore pressures inside the embankment.

Figure 9 below shows the design principles of a reinforcement type 3 .

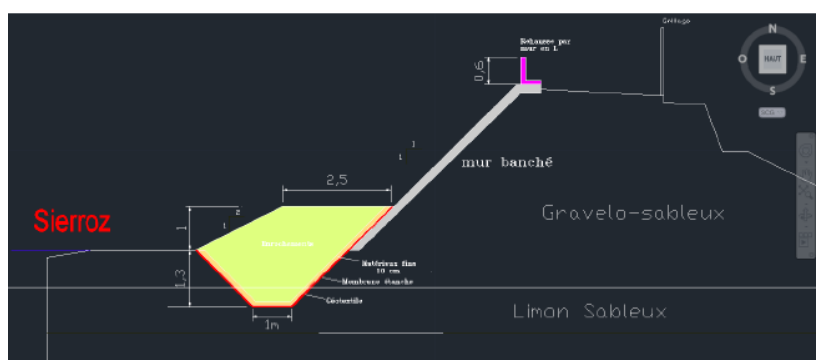

Figure 9. Reinforcement design of the embankments by rockfills on the upstream toe

The main drawbacks of this solution are:

- It is necessary to remove all vegetation and trees, including their roots, located in the riverbed. Thus, this solution has a high environmental impact.

- Despite this reinforcement, the embankments could breach if a flood flow larger than the 100 year return period flow occurred.

\subsection{Reinforcement by sheet piles}

By driving sheet piles from the embankment crest, this solution of reinforcement will reduce the internal erosion risks and will also allow the upstream fill of the embankment to remain stable in case of overtopping.

Sheet piles will also be used to enhance the crest elevation, in order to avoid any overtopping flow during a 100 year return period flood.

$300 \mathrm{~m}$ of embankment on the right rim and $280 \mathrm{~m}$ of embankment on the left rim need to be reinforced with that solution.

This reinforcement's design improves the following defence barriers of the embankments:

- There is no more risk of overtopping during a 100 year return period thanks to the crest elevation enhance by the sheet piles. Moreover, the breaching risk by overtopping is also avoided for larger floods than the 100 year return period one.

- The risk of internal erosion is avoided by the grout curtain made by sheet piles in the foundation.

- Stability of the embankments is provided by the shoring function of the sheet piles.

The potential risks of this solution are due to vibrations during driving the sheet piles. Potential impacted structures are the railways on the railway bridge and houses located near the embankments. In order to assess this impact, tests of driving sheet piles on a small linear of the right rim embankment crest near the railway have been performed (Figure 10).

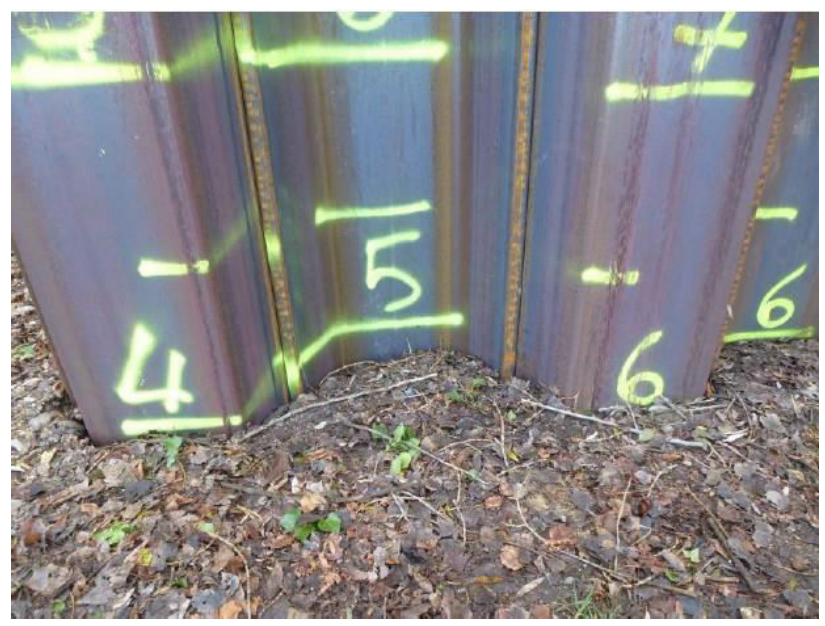

Figure 10. Test of sheet piles driven

These tests have shown acceptable vibrations for the neighbouring houses as well as for the railway bridge, excepted in the first $15 \mathrm{~m}$ from the bridge. In this section, a solution of reinforcement of the upstream face of the embankment should be chosen. 
This sheet piles solution has a lower impact on the environment. Indeed, sheet piles driving needs to cut most of the trees, but without removing them with their roots. It implies a temporary impact on the vegetation and trees located in the riverbed during works, but no irreversible impact.

\subsection{Costs}

Cost estimates for both reinforcement solutions are:

- Reinforcement of the upstream face: $2.2 \mathrm{M} €$.

- Reinforcement by sheet piles driving: 2.7M€.

\subsection{Choice of the reinforcement solution}

Criteria used by the city of Aix-les-Bains to choose a reinforcement solution are triple:

- Financial.

- Technical: level of protection and safety.

- Environmental impacts.

According to these criteria, the reinforcement by sheet piles driving appeared to be the best even if its cost is slightly higher. Two main arguments for this solution are:

- Safer solution by avoiding failure by overtopping for larger floods than the 100 year return period one.

- Lower environmental impact, with no need to remove large trees with their roots located in the riverbed during works.

\section{Surveillance project}

The second project launched by the city of Aix-lesBains, following the conclusions of the safety assessment study, is related to the embankments' surveillance.

Its objective is to design and realize a monitoring system and an early-warning system in order to perform real-time surveillance during floods and to be able to alert inhabitants living in the High Risk Area when the risk of embankment's failure becomes highly probable.

EDF and geophyConsult have been in charge to perform this second project.

Surveillance guidelines have been written and describe three types of surveillance:

- Periodic surveillance outside flood periods.

- Surveillance during floods.

- Post-seismic surveillance. paper.

Only surveillance during floods is presented in this

The governing idea of the surveillance during floods designed for the Sierroz embankments is to perform a real-time surveillance including visual inspections and some monitoring measurements that could lead to alert the neighbouring population if a high risk of breaching is assessed.

The criterion used to launch surveillance during flood is a water level (called "N1") on the upstream face of the embankments. Once the Sierroz River's level reaches the level "N1", a gauge located on the upstream concrete wall of the left rim embankment (Figures 11 and 12) sends automatically a SMS to the geophyConsult and EDF engineers in charge of this surveillance.

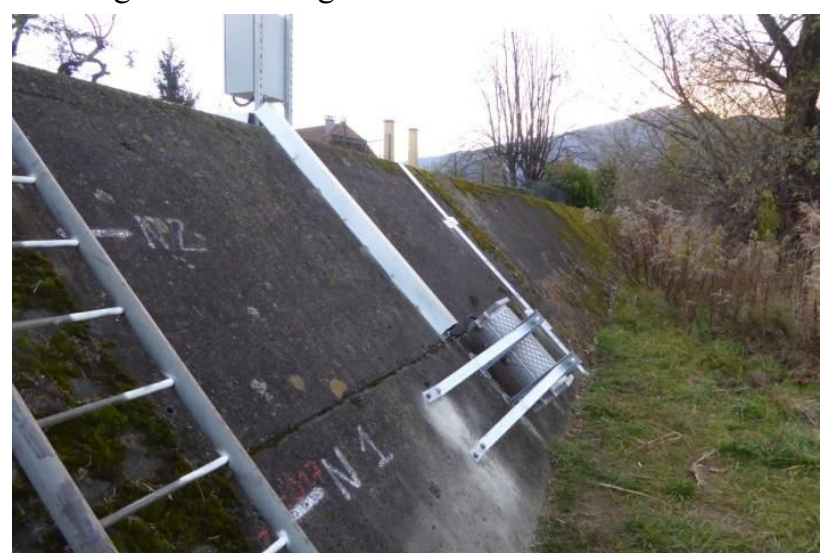

Figure 11. Automatic system of river level N1 detection

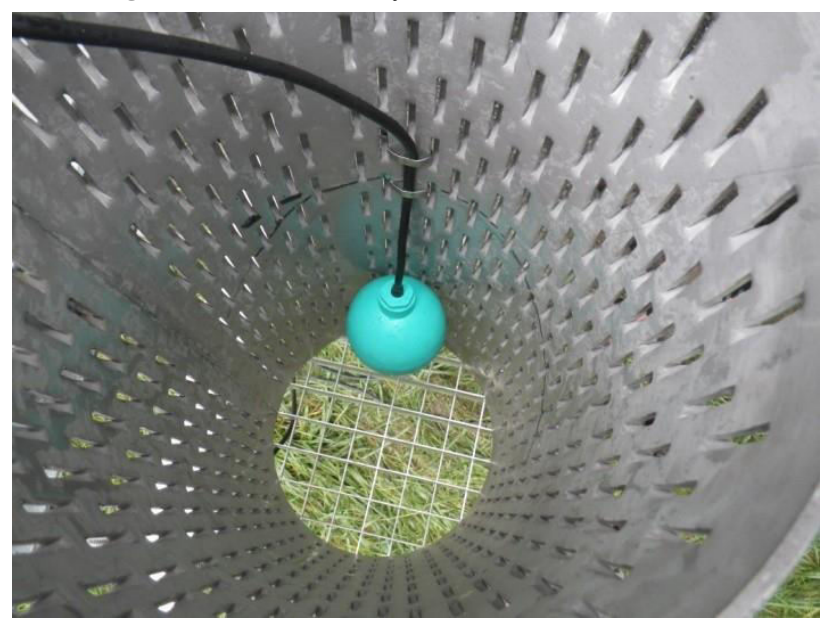

Figure 12. Zoom on the gauge for river level N1 detection

The "N1" level corresponds approximately to the maximum level reached during a 2 year return period flood.

Once geophyConsult and EDF engineers receive an SMS alert from the automatic system, they must go to the embankments and start the real-time surveillance in the 2 upcoming hours. Their surveillance remains until the river level goes down the "N1" level.

Real time surveillance of the Sierroz embankments consists in visual inspections, water level measurements on a scale installed near the automatic device (Figure 13) and piezometric measurements in the four piezometers installed were core drillings had been performed.

If during this real-time surveillance, engineers detect signs of a highly probable risk of breach (water level reaching a "N2" level which corresponds to a water level very near the crest level ahead the railway bridge, beginning of piping, large slope sliding), they have to launch an alert to the neighbouring population after validation by phone by the city of Aix-les-Bains. 
The alert procedure relies on two different systems:

- A sound alarm, located on the top of a church's roof, located near the Red bridge.

- An automatic phone call system.

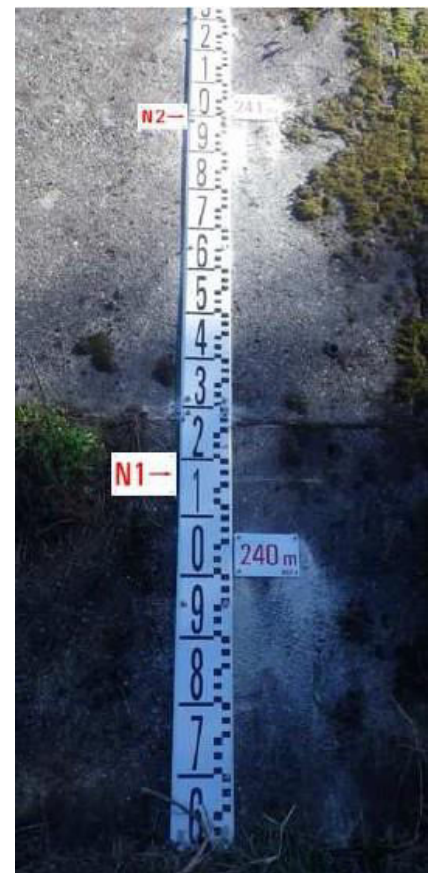

Figure 13. Scale for water level measurements located on the upstream concrete wall

The sound alarm was designed to be audible in the High Risk Area. Height broadcasters are fixed at the top of a mast above the church's roof (Figure 14).

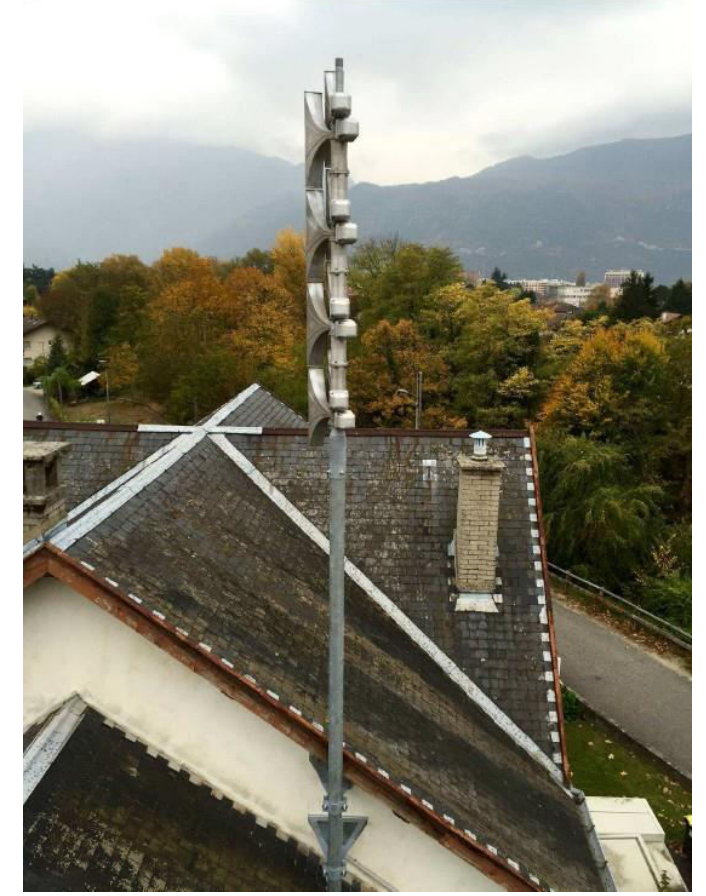

Figure 14. Sound alarm installed above the church's roof

In addition to the sound alarm, an automatic phone call alert is launched at the same time. Every inhabitant living in the High Risk Area is automatically called by this system and informed of an imminent risk of embankment breach.
After having been informed by the sound alarm and the automatic phone call system, inhabitants living in the High Risk Area have to reach as quickly as possible safe parts of their home and wait for rescue.

\section{Conclusion}

Sierroz embankments are common examples of embankments located in an urban area which appeared recently unsatisfactory in their role to protect population against flood risk.

The city of Aix-les-Bains decided to improve the protection level offered by these embankments and launched successively a safety assessment study and projects for structural reinforcement and real-time surveillance during floods.

A precise assessment of the safety margins of the embankments has firstly been performed leading to a reinforcement design. In addition, an innovative methodology for real-time surveillance during floods has been defined and has started to be applied, using conventional and cost-effective technologies.

\section{References}

1. Courivaud J.-R., Fry J.-J., Girard B. (2013). EDF Methodology of Safety Assessment Studies of Embankment Hydraulic Structures. ICOLD Symposium 2013, Theme 1.D. August 2013, Seattle, USA.

2. Courivaud J.-R., Girard B., Fry J.-J. (2013). Méthodologie EDF de diagnostic de sûreté des ouvrages hydrauliques en remblai de grand linéaire. Exemple d'application aux digues du Sierroz à Aixles-Bains. Digues maritimes et fluviales de protection contre les submersions. $2^{\text {ème }}$ colloque national. Digues 2013. 12- 14 juin 2013, Aix-enProvence, France. 